\title{
Program for ultralydsymposium i regi av Norsk forening for ultralyddiagnostikk (NFUD)
}

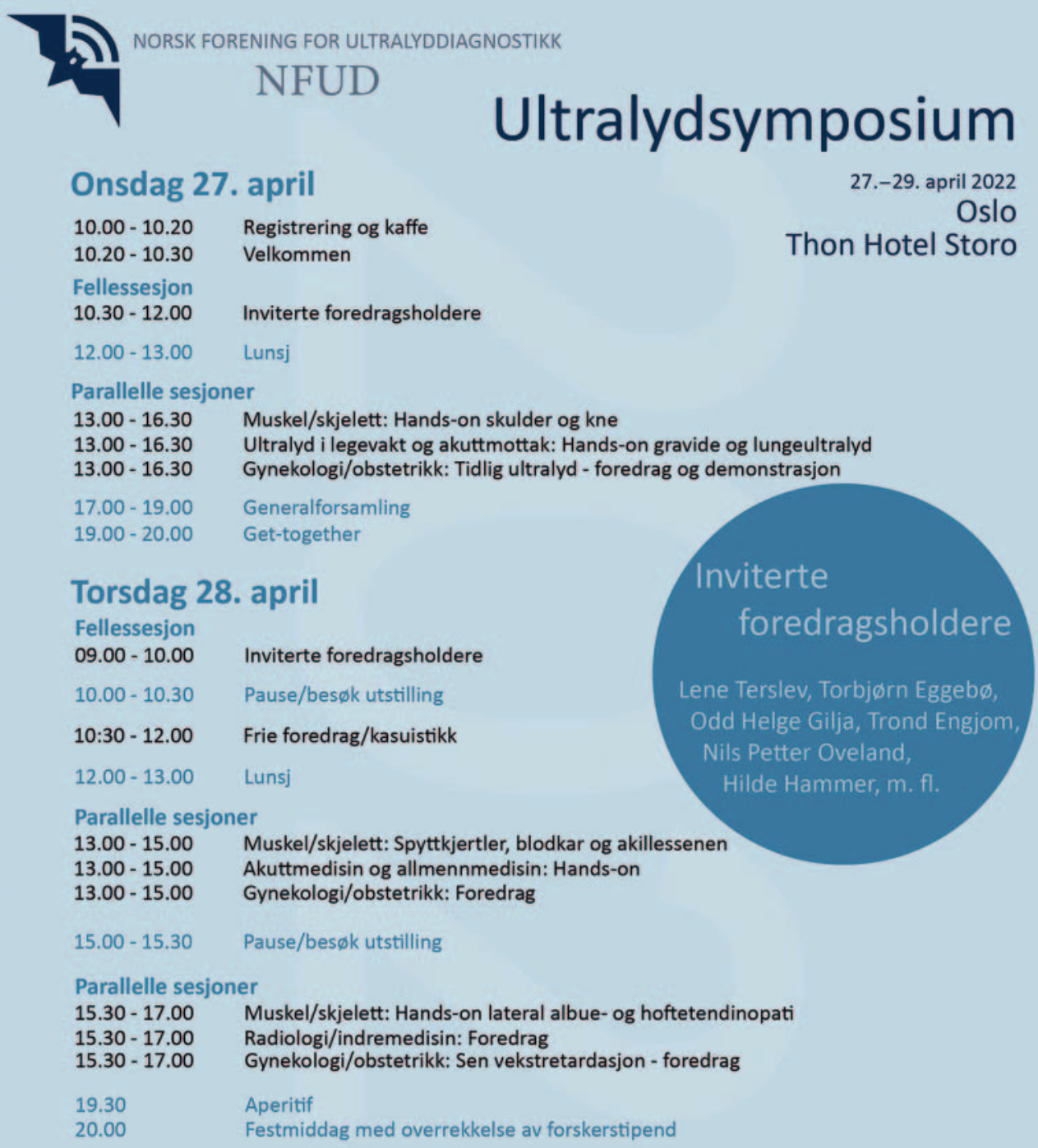

Fredag 29. april

Fellessesjon $09.00-10.30$

$10.30-10.45$

Frie foredrag/kasuistikk

$10.45-12.15$

Pause

$12.15-12.30$

$12.30-13.30$

Inviterte foredragsholdere

Avslutning og overrekkelse av pris for beste frie foredrag Lunsj 